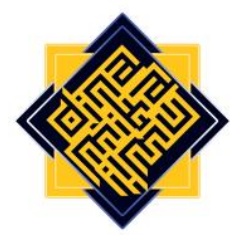

\title{
Education Financial Management during Covid-19 Pandemic of Islamic Universities in South Kalimantan
}

\author{
Riinawati \\ UIN Antasari Banjarmasin, Indonesia \\ e-mail:riinawati@uin-antasari.ac.id
}

\begin{abstract}
The purpose of this study was to determine the management of education financing in Islamic Universities in South Kalimantan. This research is in the form of descriptive qualitative with a library research data collection approach. The focus of this research will be to observe how the management of education financing in Islamic Universities throughout South Kalimantan, which consists of 13 educational institutions, both public and private categories. The results of this research show that the Covid-19 pandemic cannot be denied, causing the dropout rate to soar, due to the inability of students to pay their tuition fees. However, several campuses in South Kalimantan provide a policy of cutting payments and delaying payments so that students can continue to carry out the education process well. The financial management of Islamic higher education institutions in South Kalimantan during the Covid-19 pandemic has been carried out as effectively as possible. This is to maintain accountability and transparency to get good grades before getting crosssubsidy funds from the Government. The conclusions of this study are: the impact of Covid-19 has a very significant effect on education financing at Private Islamic Colleges in South Kalimantan but not at State Islamic campuses and the management of education financing amid the Covid-19 pandemic should be carried out very strictly.
\end{abstract}

Keywords: covid-19, education financing, Islamic universities management 


\section{Riinawati}

\section{A. Introduction}

The quality of a country can be seen from several factors, including the education factor. An educational institution is an institution that is prepared to provide the needs of quality human resources. Quality human resources will improve the quality of a country. Therefore, efforts to improve the quality of natural resources cannot be separated from education. Permana et al. (2010) state that quality education is seen from the input, process, output, and outcome side. Quality education inputs are quality teachers, quality students, quality curriculum, quality facilities, and various aspects of quality education providers. A quality education process is a quality learning process. Quality education outputs are graduates who have the required competencies. The outcome of quality education is graduates who can continue to higher education or are absorbed in the business world or the industrial world (Azhari \& Kurniady, 2016).

Educational institutions as an organization have dual functions in and out. Functions In educational institutions function to manage the various resources it has to survive and develop the institution carrying out its mission. In addition, educational institutions are bodies and institutions that have multiple responsibilities both internally and externally. External functions include its position as an organization that provides educational facilities to students to carry out a series of learning processes with various strategies so that they can improve their skills, capabilities, and competencies, both cognitive, affective, and psychomotor. The internal functions include all the resources and efforts as well as the strategy of the agency to manage the resources of the various resources it has so that it can continue to exist, process, and develop in a better direction and not out of the vision and purpose of its formation. On the other hand, so that the institution can survive and stand firm during any situation that shakes the continuity of the operation of educational facilities.

As mandated in the Republic of Indonesia Law No. 20 of 2003, education is a series of conscious efforts that have been conceptualized to carry out learning and teaching activities or learning processes that support and encourage students to actively develop their potential in the fields of religious spirituality, noble character, controlling noble self and personality as well as in the intellectual field including intelligence of reason, breadth of knowledge and skills and skills that are reliable in various fields so that they can be useful both for themselves, their families, communities and the nation and state. Thus, national education is useful to encourage people to become insightful, literate, moral, authoritative, qualified, and wise in living life during global life (Mulyono, 2016). The vision of national education is to realize the education system as a strong and authoritative social institution to empower all citizens of developing countries to become quality human beings so that they can proactively respond to the challenges of an ever-changing era.

Education is an important indicator in assessing the progress of a country's development. One classic problem that continues to plague the higher education system in Indonesia is the financing of education that is not by its realization. Thus, being an educational institution is not considered professional and the educational process in the institution is doubted (Muftahu, 2020). Educational institutions at any level can be said to 
be professional when they have good, transparent, and efficient governance in realizing an optimal and synergistic learning process (Matin, 2014). So we need comprehensive management in managing and creating educational institutions that can answer the needs of students and accommodate the basic needs of educational staff and administrative staff as the motor of the implementation of teaching and learning activities. On the other hand, good education financing management must also be managed professionally to be able to build all facilities and infrastructure that at least meet sufficient standards for the implementation of the educational process (Ferdi, 2013).

Of the many basic components of education, the things that are considered important are money and financing. Money is seen as the blood of an organization in improving the quality of education and the quality of human resources itself. But some think that money is like a horse in an organization. The organization is like a cart. Carts don't run without being pulled by horses. Education does not run without a cost or budget. Thus, an important factor that determines the quality of education and the functioning of human resource education is the cost of education (Zebua, 2021).

Funding for education focuses on efforts to distribute the benefits of education and the burden that must be borne by the community. Cost is simply the amount of money spent to support the educational process or services provided to students. Education finance relates to the distribution of the tax burden in various types of human group taxes as well as the method of transferring taxes to schools. The most important thing in financing education is the amount of money that must be spent, where is the source of the money obtained, and to whom the money should be spent (Munir, 2013).

Educational financing contributes quite urgently in supporting the continuity of the course of education. Where the course of activities can be realized optimally when all plans can be fulfilled, both requirements and plan to achieve educational targets. Educational funding is useful for meeting all operational needs, full implementation of education starting from the readiness of learning facilities and infrastructure, salaries and salaries of teachers, school and campus employees, and staff as well as other equipment that supports the improvement of learning activities as well as improving the skills of educators, librarians, administrative staff through a series of quality training and professional certification. It can be said that all aspects of the implementation of education require a fee. For this reason, without funding, the quality of education implementation will not run optimally (Arikunto, 2008). In all efforts to achieve educational goals, the cost and financing of education have a very decisive role. Almost no educational effort can ignore the role of costs, so it can be said that without costs, the educational process cannot run optimally (Munir, 2013).

The financing of education in the private sector is entirely sourced from public funds, although there is assistance from the government it is not too significant to be used as a reference in determining policies, the quality of private higher education is of course very dependent on how the financing is managed. Good financing management is one of the keys to the success of an educational institution to advance or improve its quality (Abidin, 2017). According to Law no. 20 of 2003 article 35 concerning National Education 


\section{Riinawati}

Standards, it is stated that national education standards are used as a reference for curriculum development, education personnel, facilities and infrastructure, management, and financing. Through strategic planning in the field of education, educational institutions can prepare outputs. Many factors affect the quality of schools including organizational culture, principal leadership, organizational climate, infrastructure, teacher performance, and financing. The cost of education has a positive influence through leadership and educational management factors and competent educators in improving educational services through quality improvement (Waliyah et al., 2021).

Firdaus (2004) in his research reveals that an effective financing system can achieve quality education and ensure the survival of private educational institutions. Educational funding sources originating from students are great potential in implementing education management and are capital for the sustainability of education. The management system and management of fundraising for education funding should be focused on partnership strategy efforts (Sonedi et al., 2017).

Reviewing university finance from an international perspective that the shift in financing from the government to private sources (Usher, 2009) and this shift has serious consequences for universities and students. The balance between public and private education funding is an important policy at this time. For example, Canada, Portugal, and Spain experienced a decline in education funding between 2007 and 2012, while other countries, despite the economic crisis, managed to increase aid for student studies at colleges or universities (Jongbloed \& Vossensteyn, 2016). In Indonesia, the implementation of Government Regulation No. 19 of 2005 has implications for the need to develop financing standards through standardization of education costs which include operational costs, investment costs, and personal costs (Rida Fironika, 2011). As mandated in the 1945 Constitution (amendment), article 31, paragraph 4, the government must determine $20 \%$ of the budget for education costs from the state budget. The education financing system in Indonesia involves elements of the government, the public, and the private sector to improve equity and the quality of education (Lorensius \& Ping, 2021).

Recently, the world was shocked by the emergence of the COVID-19 pandemic outbreak that began in China, Wuhan (Yuliana, 2020; Lorensius \& Ping, 2021). The COVID19 pandemic has attracted global attention, so that on January 30, 2020, WHO (World Health Organization) declared COVID-19 as a public health emergency of international concern. Reporting from an online article Halodoc.com accessed on June 12, 2021, Coronaviruses are a large family of viruses that cause mild to moderate upper respiratory tract infections, such as the flu. Many people are infected with this virus, at least once in their life. However, some types of coronavirus can also cause more serious diseases, such as Middle East Respiratory Syndrome (MERS-CoV), Severe Acute Respiratory Syndrome (SARS-CoV), Pneumonia. COVID-19 or also known as Novel Coronavirus (caused an outbreak of pneumonia in the city of Wuhan, China in December 2019, and spread to other countries starting January 2020. Indonesia itself announced a case of covid 19 from March 2020 (Waliyah et al., 2021) 
Since the announcement of the first Covid-19 case in early March 2020, education has been the sector most affected. Covid-19 is a kind of flu that attacks the respiratory system and is highly contagious. The government immediately closed schools and campuses to change the classroom learning system to distance learning (PJJ) or online learning from home. This is taken to anticipate the wider spread of Covid-19 if the teaching and learning process in the classroom is still activated. The Covid-19 pandemic has finally spread all over the world. Data as of July 3, 2021, shows that 183 million people have been infected with Covid-19 and 3.97 million have died. In Indonesia alone, 2.23 million were positively infected, 1.9 million people were declared cured and as many as 59,534 died from Covid-19. So this virus is very dangerous and deadly, especially most of them have a history of other comorbidities or comorbidities (Kompas.com, 2021).

The Covid-19 pandemic has forced social distancing policies, or in Indonesia, it is better known as physical distancing (maintaining physical distance) to minimize the spread of Covid-19. This policy is attempted to slow down the spread of the Coronavirus in the community (Waliyah et al., 2021). This situation also affects various aspects of people's lives, one of which is in the field of education. The effects of the pandemic caused the national economy to decline to minus 5.23\% (Ping, 2021). The Ministry of Education and Culture (Kemdikbud) responded with a policy of learning from home, through online learning. The presence of the Covid-19 pandemic, in addition to changing the education process, also disrupted education financing. Naturally, the Covid-19 caused economic paralysis so that it also affected the delay in education financing paid by students, so that in the end the cash flow of private education decreased so that the income of private educational institutions was threatened.

Based on this, the attention of universities related to education financing is very important to improve the effectiveness and performance of higher education institutions. Ferdi's study (2013) identifies an effective and efficient education financing model as the human capital model, where the financing aspect can affect the level of income productivity of a person or group so that in the end it can contribute to the speed of economic growth and development. In line with the mandate of Law Number 20 of 2003 Article 46 paragraph (1) that financing education is a shared responsibility between the central government, regional governments, and the community. Education funding is an important and inseparable component in the administration of higher education, especially during the current pandemic. The results of the study of Al-Samarrai et al. (2020) reported that economic shocks during the Covid-19 pandemic it was significantly bigger than the financial crisis globally in 2008/2009. Government policy to stop the spread of the pandemic outbreak caused many countries to experience a decline in demand and supply in trade and falling commodity prices. This effect also increases the unemployment rate (Loayza \& Pennings, 2020). That matter impacts students' ability to pay tuition fees (Budi, 2020). Coupled with the findings of that online learning during the pandemic requires students to be active internet by buying internet quota and paying for electricity costs, this is resulting in increased spending. According to Al-Samarrai et al., (2020) when campuses begin to reopen, it is very important to allocate funds in addition to assisting 


\section{Riinawati}

universities and other educational institutions in address the problem of financing education and reduce the possibility the number of students dropping out of school (Snilstveit et al., 2017).

The decline in the income of private educational institutions is because many parents or guardians of students experience salary cuts in their workplaces, some even experience layoffs (PHK) so that it has an impact on the delay in paying their children's monthly or semester tuition fees, even though the largest income comes from private educational institutions. is from the monthly money of his students. This delay in paying monthly or semester tuition fees has caused the managers of these institutions to be unable to pay their teachers/lecturers and staff, and there are even educational institutions that have taken layoffs for these teachers/lecturers and staff (Zebua, 2021).

Therefore, the researcher wants to conduct an in-depth study of education financing management with a focus on Islamic universities in South Kalimantan. Considering that Islamic higher education in Kalimantan is mostly in the form of the private sector, education financing of course relies on the management of payment funds from students and investors. Understandably, most students will experience delays and delays in paying their tuition fees. So, professional financial management is needed so that Islamic high schools in South Kalimantan can still run optimally even though the teaching method fully relies on learning from home or the use of digital technology and internet networks.

\section{B. Literature Review}

Management comes from the word to manage which means to regulate. Arrangements are made through a process and are arranged according to the order of the management functions. Thus, management is a process to realize the desired goals (Waliyah et al., 2021).

Stoner \& Freeman, management is a process of planning, organizing, leading, and supervising the work of organizational members and using all available organizational resources to achieve clearly stated organizational goals. 10 Another opinion Engkoswara \& Ann Komariah, provides a definition: Management is a continuous process that contains abilities, special skills possessed by a person to carry out an activity both individually and with others in coordinating and using all resources to achieve organizational goals productively and efficiently. 11 According to William Springel, Management is that function of an organization. Enterprise which concerns the direction of business and control of the various activities to attain the business objectives. He views management as a company activity (which should apply to non-company activities as well), and management is seen as a corporate function in the form of providing direction and control of various activities to achieve goals (Sonedi et al., 2017).

Educational financing management means managing the funding aspect in all aspects related to the process of providing education to achieve the planned results and goals (Thamrin, 2012). Education financing as stated in Government Regulation No. 48 of 2008 that education financing is a shared responsibility between the government, local governments, and the community. Meanwhile, the government budget in the field of 
education as mandated by the 1945 Constitution of the Republic of Indonesia Article 31 is $20 \%$ of the APBN and APBD during the current fiscal year. This means that government funding in the education sector is quite large. However, due to the Covid-19 pandemic, the allocation in the education sector was also cut and adjusted to the health and social sector to cope with the spread of Covid-19 and the impact of the crisis.

Reviewing education financing is closely related to the theory of the education economy. Education makes a major contribution to the development of socio-economic life through increased knowledge, skills, abilities, attitudes, and productivity. From the point of view of economic theory education, especially the human capital approach, the financing aspect is considered as part of the educational investment that determines the level of productivity individual or group (Lorensius \& Ping, 2021).

There are several studies conducted by previous researchers on the management of the Education Fund budget. First, research conducted by Motsamai \& Jacobs (2011) in various schools in South Africa shows that policies related to the budget or financing of school education are unavoidable. In this case, the budget policy has directed schools to manage school budgets well because it has an impact on improving the quality of the school itself.

Second, research by Yau \& Cheng (2011) in various elementary schools (SD) in Hong Kong shows that schools should decentralize their education budget planning to suit their school conditions and policies. In addition, teachers should also be involved in budget planning for the financing of education in schools. Meanwhile, the principal has the responsibility to oversee the use of the budget that has been delegated to various groups to manage the budget.

Third, research conducted by Otieno et al. (2016) in various schools in Kenya shows that the budget management team or school finances need training in budget management to avoid problems with good and successful school budget management. Fourth, research conducted by Ho (2010) in various schools in Taiwan shows that the schools studied have implemented school-based financial management policies to solve various problems related to the education budget. The result is that the implementation of the school-based school funding policy in Taiwanese schools is very effective, and the government is expected to adopt the policy in all schools as well, to avoid problems with the management of the education budget.

Based on the results of several studies mentioned above, it can be concluded that the management of the Education Fund budget by an educational institution or agency, taking into account various existing factors, is very important. These factors vary according to the conditions of each educational institution and the objectives to be achieved by each educational institution.

However, some studies by previous researchers have focused on school administration. In this regard, no prior investigation has been directed at the university or college organization beforehand. Note that universities or colleges have different ways of processing education budgets. Therefore, it is very important to carry out this research. 


\section{Riinawati}

\section{Research Methodology}

This article was compiled based on qualitative-descriptive research, namely research presented in the form of actual, chronological, and comprehensive data elaboration to answer the formulation of the problem. Where the researcher relies on the five senses and scientific perspectives in the process of problem formulation, identification, data collection to the analysis process, and formulating discussions and conclusions at the end (Afrizal, 2015). Qualitative-descriptive research is a measurable choice, considering the study raised by the researcher relates to explicit efforts to manage Islamic higher education during the Covid-19 pandemic. Where researchers will reveal how the reality and performance of the rectorate in presenting comprehensive management in difficult economic situations and situations that cannot be predicted when it will end.

The theories and concepts that the researcher presents in this research are observational studies and cross-checking phenomena in the field. Where the focus of the research is directed at a series of analyzes on theories, concepts, innovations and strategies for financing management of Islamic high school education in South Kalimantan, of which there are 13 educational institutions, namely; UIN Antasari Banjarmasin, Islamic University of Borneo Muhammad Arsyad Al-Banjary Banjarmasin, Islamic Polytechnic Sheikh Salman Al-Farisi Tapin Regency, STEI Madani Banjarmasin, STIO Amuntai Hulu Sungau Utara, STAI AI Falah Banjarbaru, STAI Al Jami Banjarmasin, STAI AI Washliyah Hulu Sungai Tengah, STAI Darul Hijrah Banjar, STAI Darul Ulum Hulu Sungai Selatan, STAI Darussalam Banjar, STAI Rakha Amuntai Hulu Sungai Utara, STIT Darul Ulum Banjarbaru.

The findings of the data in this research were collected using the library research data collection method (library study). Namely collecting data through in-depth and critical reading of books, journals, and online media coverage about the management of Islamic high school education financing in South Kalimantan during the Covid-19 pandemic. The review of the analysis taken by the researcher in this research can be categorized into three stages; First, the data reduction efforts carried out by the researcher as well as grouping urgent data and information according to the themes taken at the same time also set aside which parts are less relevant; Second, data presentation efforts in which the researcher will systematically present all connected data that has been processed and compiled comprehensively; Third, the effort to conclude critically and analytically, where the researcher after conducting an in-depth analysis then draws the most appropriate and measurable conclusions as relevant interpretations of the issues highlighted in this research (Afrizal, 2015).

\section{Findings and DIscussion}

\section{The Impact of Covid-19 on Financing Islamic Universities in South Kalimantan}

The COVID-19 pandemic has had a huge impact, especially in the economic sector, so that other sectors are also affected, such as the education sector (Waliyah et al., 2021). It is undeniable that the Covid-19 pandemic has had a significant effect on the financing of education in all Islamic Universities in South Kalimantan. UIN Antasari Banjarmasin, 
Islamic University of Borneo Muhammad Arsyad Al-Banjary Banjarmasin, Islamic Polytechnic Sheikh Salman Al-Farisi Tapin Regency, STEI Madani Banjarmasin, STIQ Amuntai Hulu Sungau Utara, STAI Al Falah Banjarbaru, STAI Al Jami Banjarmasin, STAI Al Washliyah Hulu Sungai Tengah, STAI Darul Hijrah Banjar, STAI Darul Ulum Hulu Sungai Selatan, STAI Darussalam Banjar, STAI Rakha Amuntai Hulu Sungai Utara, STIT Darul Ulum Banjarbaru. When classified, there are two types of public and private educational institutions. There is only one state Islamic higher education institution, namely UIN Antasari Banjarmasin, while the other 12 are classified as private educational institutions. This classification is important considering the sources of funding for the two are different. If the state Islamic higher education institutions of course still receive funding from the government which is quite large in addition to the tuition fees paid by students. Meanwhile, private higher education institutions only rely on tuition fees from students and a small portion of government funding and donors or investors.

The conditions during the Covid-19 pandemic which caused the economic downturn to the crisis, however, had an impact on the ability of students to pay for their tuition fees. On the other hand, the allocation of funds budgeted by the government in the education sector was also slightly hampered because more was sucked into the allocation of spending in the health sector and social economy nets due to the impact of Covid-19 which caused economic paralysis of the lower classes. In this way, education financing automatically began to experience delays. At the State Islamic University of UIN Antasari, financial income is not too much stagnation considering that the post for education expenditure from the APBN and APBD can still cover the course of online learning. However, it is different from the 12 private Islamic Universities that have experienced economic stagnation because most of their students were affected by Covid-19 and were late and could not even afford to pay tuition. This tuition fee from the community is a source of income to be used by educational institutions to finance the educational process. On the other hand, sources of income from other community sponsors are also experiencing stagnation because the impact of Covid-19 on the economy in South Kalimantan is quite deep. Automatically, private Islamic higher education institutions only wait for cross-subsidies from the Central Government and Regional Governments to fulfill their education financing.

The Covid-19 pandemic cannot be denied, causing the dropout rate to soar, due to the inability of students to pay their tuition fees. However, several campuses in South Kalimantan provide a policy of cutting payments and delaying payments so that students can continue to carry out the education process well. On the other hand, the campus guarantees students not to resign in a pandemic situation that is not clear when it will end. So that the campus urges students to continue to follow the learning process from home following the mandate of the legislation so that they can complete the stages of education in the education plan that has been prepared by the lecturers. However, some Islamic private campuses cannot provide tuition fees relief so that they cannot prevent some of their students from being forced to resign. 


\section{Riinawati}

\section{Education Financing Management at Islamic Universities in South Kalimantan}

Stoner and Freeman, management is a process of planning, organizing, leading, and supervising the work of organizational members and using all available organizational resources to achieve clearly stated organizational goals. 10 Another opinion Engkoswara \& Ann Komariah, provides a definition: Management is a continuous process that contains abilities, special skills possessed by a person to carry out an activity both individually and with others in coordinating and using all resources to achieve organizational goals productively and efficiently. 11 According to William Springel, Management is that function of an organization. enterprise which concerns the direction of business and control of the various activities to attain the business objectives. He views management as a company activity (which should apply to non-company activities as well), and management is seen as a corporate function in the form of providing direction and control of various activities to achieve goals (Sonedi et al., 2017).

The definition of management is defined in various ways, depending on the point of view, beliefs, and understanding of the definition maker. In general, the notion of management is the management of a job to obtain results to achieve predetermined goals by moving other people to work. The management of workers consists of various kinds, education, social services, sports, health, science, and others. Almost every aspect of human life requires management, therefore, management exists in every aspect of human life where a collaboration (organization) is formed (Herujito, 2011).

Educational financing management means managing the funding aspect in all aspects related to the process of providing education to achieve the planned results and goals (Thamrin, 2012). Education financing as stated in Government Regulation No. 48 of 2008 that education financing is a shared responsibility between the government, local governments, and the community. Meanwhile, the government budget in the field of education as mandated by the 1945 Constitution of the Republic of Indonesia Article 31 is $20 \%$ of the APBN and APBD during the current fiscal year. This means that government funding in the education sector is quite large. However, due to the Covid-19 pandemic, the allocation in the education sector was also cut and adjusted to the health and social sector to cope with the spread of Covid-19 and the impact of the crisis.

Reviewing education financing is closely related to the theory of the education economy. Education makes a major contribution to the development of socio-economic life through increased knowledge, skills, abilities, attitudes, and productivity. From the point of view of economic theory education, especially the human capital approach, the financing aspect is considered as part of the educational investment that determines the level of productivity individual or group (Lorensius \& Ping, 2021).

In terms of financial administration, especially financial administration in the field of education, a distinction is made between costs and expenditures. Cost is the number of funds that are estimated to need to be provided to finance certain activities, such as academic activities, student activities, and so on. While expenditure (expenditure) is the number of real funds spent to finance certain activity units, such as student practicum activities. Therefore, there is often a discrepancy between budgeted costs and real 
spending. Costs can be interpreted as expenditures which in economic terms can be in the form of money or other monetary forms. The cost of education is an important thing in the implementation of education. It can be said that the educational process cannot run without financial support. The cost of education is one component of instrumental input (instrumental input) which is very important in the implementation of education, especially in schools. Based on the source, the cost of education can be classified into four types: first, the cost of education issued by the government. Second, education costs are incurred by the community or parents/guardians of students. Third, education costs are incurred by the community, not parents of students, for example, sponsors from financial institutions and companies. And fourth, from the educational institution itself. Each of these sources is a strategic post in the circulation of education financing to support educational programs that are scheduled, both by the educational institutions themselves as a forum for empowerment and development, as well as the government as a party that has policies in budgeting which institutionally has the main responsibility and impetus for development. the direction of the effectiveness and efficiency of educational activities. Therefore, the cost factor is very influential on the implementation of education (Munir, 2013 ; Waliyah et al., 2021).

There are several types and classes of education costs studied in this article, namely: 1) direct costs are defined as expenditures of money that directly finance the implementation of education, teaching, research and community service (Idochi, 1991), 2 ) routine costs (recurrent costs), are costs used to finance educational operational activities for one fiscal year, 3) indirect costs can be interpreted as costs that generally include the loss of student income because they are attending education (earning foregone by students), free tax burden due to the non-profit nature of schools (cost of tax exemption), free rental of school equipment that is not used directly in the education process and depreciation as a reflection of the use of school equipment that has been used for a long time (implicit rent and depreciation) (Fattah, 2000), 3) monetary costs are all forms of expenditure $n$ in the form of money, either directly or indirectly issued for educational activities, 4) non-monetary costs are all forms of expenditure that are not in the form of money, although they can be assessed in the form of money, either directly or indirectly, which are issued for educational activities, For example, material, time, energy, etc.

The researcher sees that the financial management of Islamic higher education institutions in South Kalimantan during the Covid-19 pandemic has been carried out as effectively as possible. This is to maintain accountability and transparency to get good grades before getting cross-subsidy funds from the Government. Effective and efficient financing of education is a shared responsibility, both the Government and the community. Efficiency means that it must be implemented in all agencies, including in the field of education, especially in the implementation of education it is very limited. Efficiency always compares two things, namely input with output. In this case, the cost of education can measure efficiently by comparing costs with outcomes (Abidin, 2017). It is necessary to build mutual trust, both between the Government and the community, and the community and the community itself can be grown. Openness, participation, 


\section{Riinawati}

accountability in the implementation of education from planning, implementation, and supervision are the keywords to realize the effectiveness of education financing. Income posts in private high schools are not in a definite direction, so they make a series of savings and only carry out activities and expenditures for goods that are needed, so there is no diversion of the budget that is not per the most basic lesson plans. This shows that the control of expenditure plans is adjusted to the potential income that will be received by a private Islamic higher education institution. It is different with state Islamic higher education institutions whose funding posts have been mostly covered by the APBN and $A P B D$, the funding process is not too different from the period before the pandemic.

Given the important role of financing in the learning process, it is unavoidable to have good financing governance in education budgeting. This financial governance is hereinafter referred to as financing management. Related to education financing, many problems arise, namely, the lack of an education budget, irregularities in the distribution of education funds, and inadequate allocation of funds (Sonedi et al., 2017).

UIN Antasari can provide policies that reduce the impact of Covid-19 for its students who are affected. Where the rectorate has signed a decree to overcome student difficulties during the pandemic, namely in the form of waivers for UKT payments (Single Tuition Fees) and an extension of the UKT payment period as well providing internet quota packages that can be used for online learning from their homes. The conditions needed so that students can get waivers are by showing the completeness of one or more legal evidence/information requirements related to the status of parents/guardians, namely: (1) Death; (2) Experiencing termination of employment; (3) experiencing business losses/declared bankrupt; (4) Experiencing the closure of the place of business and (5) Significant decrease in income. This evidence is supported by valid documents, such as death certificates, termination letters, commerce court decisions, and certificates from the village head. This seems difficult for private Islamic higher education institutions in South Kalimantan to do.

Where the management of education financing in private institutions runs by carrying out several revisions to financing plans, financing realization, and seeking proportional budget meetings. Thus, it will be further assessed whether the proportion of the expenditure budget issued will have an impact on both operational expenditure and future development investment spending. However, the priority remains the effort to maximize the passage of online learning which originally required new equipment, namely the strengthening of the internet network on campus. Where the lecturers in carrying out their duties must be supported by a good internet quota so that the material assistance process to students goes well. In other words, the management of education financing both at state Islamic campuses and private Islamic campuses both show efforts to control the budget as effectively as possible and keep the campus financial balance stable even though the income post is uncertain but still managed effectively, efficiently, accountable and transparently so that the learning process can still be optimized. 


\section{E. Conclusion}

After the researcher has conducted research, it can be concluded several things, namely: first, education financing is a vital aspect in efforts to develop the national education system. Second, the impact of Covid-19 has a very significant effect on the financing of education at Private Islamic Colleges in South Kalimantan, while the financing of education at State Islamic campuses does not have much effect. This is of course based on the income budget posts of the two different institutions, where most of the funding for state campuses is supported by the APBN and APBD, while private campuses rely on the main income from the community, both students and sponsors, as well as subsidies from the APBN and APBD. Third, the management of education financing during the Covid-19 pandemic is carried out very strictly. This is evidenced by the revision of planning, management, and realization of private campus spending which is only intended for basic things, especially operational expenditures so that the education process can run optimally. Meanwhile, at state campuses, management continues to prioritize transparent, effective, and efficient aspects and also responds to crises to relieve students affected by Covid-19 by providing waivers, concessions, and internet quota assistance.

\section{BIBLIOGRAPHY}

Abidin, A. A. (2017). Manajemen pembiayaan pendidikan tinggi dalam upaya peningkatan mutu (Studi kasus pada perguruan tinggi swasta menengah di Surabaya). Jurnal Penjaminan Mutu, 3(1), 87-99.

Al-Samarrai, S., Gangwar, M., \& Gala, P. (2020). The impact of the COVID-19 pandemic on education financing. https://www.researchgate.net/publication/341393543_The_ Impact_of_the_COVID-19_Pandemic_on_Education_Financing

Afrizal. (2015). Metode Penelitian Kualitatif: Sebuah Upaya Mendukung Penggunaan Penelitian Kualitatif Dalam Berbagai Disiplin Ilmu. Grafindo.

Arikunto, S. (2008). Manajemen Pendidikan. Aditya Media.

Azhari, U. L., \& Kurniady, D. A. (2016). Manajemen Pembiayaan Pendidikan, Fasilitas Pembelajaran, Dan Mutu Sekolah. Jurnal Administrasi Pendidikan, 23(2). https://doi.org/10.17509/jap.v23i2.5631

Ferdi, W. (2013). Pembiayaan Pendidikan, Suatu Kajian Teoritis. Jurnal Pendidikan \& Kebudayaan, 19(4)

Herujito, Yayat M. (2011). Dasar-Dasar Manajemen. PT Grasindo.

Idochi Anwar, M. (1991). Biaya Pendidikan dan Metode Penetapan Biaya Pendidikan. Mimbar Pendidikan, 10(1).

Jongbloed, B., \& Vossensteyn, H. (2016). University funding and student funding: International comparisons. Oxford Review of Economic Policy, 32(4), 576-595.

Lorensius, \& Ping, T. (2021). Model Pembiayaan Pendidikan di Perguruan Tinggi pada Masa Pandemi Covid-19. Indonesian Journal of Education and Humanity, 1(2), 107-119.

Loayza, N., \& Pennings, S. M. (2020). Macroeconomic policy in the time of COVID-19: A primer for developing countries. World Bank Research and Policy Briefs, (147291).

Dinamika Ilmu, Volume 21(2), 2021 
Matin. (2014). Manajemen Pembiayaan Pendidikan; Konsep \& aplikasinya. Grafindo.

Muftahu, M. (2020). Higher Education and Covid-19 Pandemic: Matters Arising and the Challenges of Sustaining Academic Programs in Developing African Universities. International Journal of Educational Research Review, 417-423. https://doi.org/10.24331/ijere.776470

Mulyono. (2016). Konsep Pembiayaan Pendidikan. Arruz Media

Munir, A. (2013). Manajemen Pembiayaan Pendidikan dalam Perspektif Islam. Jurnal AtTa'dib, 8(2), 223-239.

Permana, J., Koswara, D. D., \& Triatna, C. (2010). A Leaderpreneurship Training Model for Elementary School Principals in the Framework for Guaranting School Qualities. Indonesia University of Education.

Ping, T. (2021). Model Pembiayaan Pendidikan Di Perguruan Tinggi Pada Masa Pandemi Covid-19. Indonesian Journal of Education and Humanity, 1(2), 107-119.

Rida Fironika, K. (2011). Pembiayaan Pendidikan Di Indonesia. Jurnal Ilmiah Pendidikan Dasar, 26(1), 43-63.

Snilstveit, B., Gallagher, E., Phillips, D., Vojtkova, M., Eyers, J., Skaldiou, D. \& Davies, P. (2017). PROTOCOL: Interventions for improving learning outcomes and access to education in low-and middle-income countries: A Systematic Review. Campbell Systematic Reviews, 13(1), 1-82.

Sonedi, S., Jamalie, Z., \& Majeri, M. (2017). Manajemen Pembiayaan Pendidikan Bersumber dari Masyarakat. Fenomena, 9(1), 25. https://doi.org/10.21093/fj.vgi1.702

Thamrin, Abdullah. (2012). Pembiayaan Pendidikan. Modul Pembelajaran di Program Pascasarjana UNJ.

Waliyah, S., Dini, S., \& Syarif, A. (2021). Manajemen Pembiayaan Pendidikan Masa Pandemi Covid-19 di SMK Gazza Wiguna 1. Transformasi Manageria: Journal of Islamic Education Management, 1(1), 77-98. https://doi.org/10.47467/manageria.v1i1. 272

Yuliana, Y. (2020). Corona virus diseases (Covid-19): Sebuah tinjauan literatur.. Wellness and Healthy Magazine, 2(1), 187-192. https://doi.org/10.30604/well.95212020

Zebua, A. M. (2021). Aplikasi Eletronik Manajemen Keuangan DIPA pada Lembaga Pendidikan Islam Negeri di Tengah Pandemi Covid-19 Sebagai Upaya WFH. Fikrotuna, 12(2), 20-50. 